Dicle Tıp Dergisi / Dicle Med J (2018) 45 (1) : 85 - 92

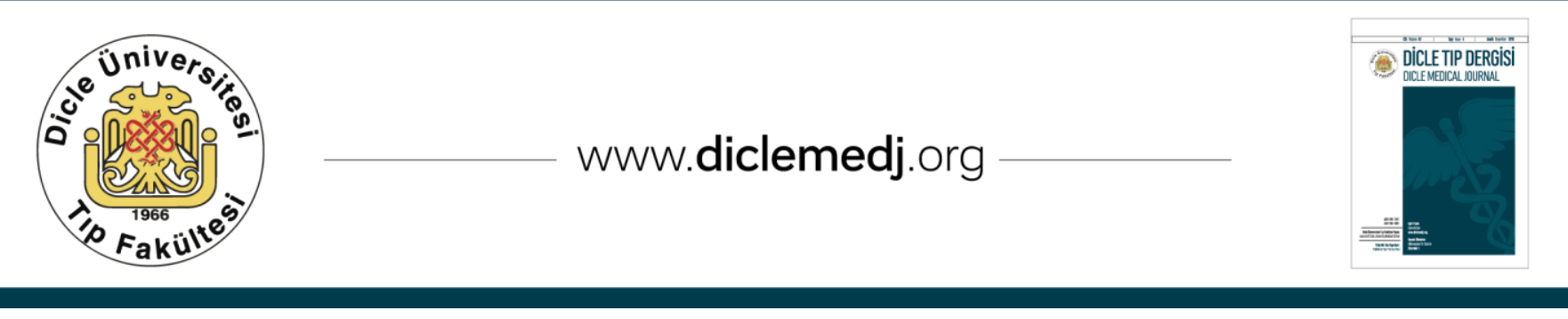

Derleme / Review

\title{
Karanlığın Mucizesi: Melatonin ve Ovaryum Etkileşimi
}

\author{
Gökçe Nur Yücel1 ${ }^{1}$, Gülnur Take Kaplanoğlu², Cemile Merve Seymen³
}

1 Gökçe Nur Yücel, Gazi Üniversitesi Tıp Fakültesi Histoloji ve Embriyoloji Anabilim Dall, Ankara, Türkiye ORCID: 0000-0003-0129-8358

2 Gülnur Take Kaplanoğlu, Gazi Üniversitesi Tıp Fakültesi Histoloji ve Embriyoloji Anabilim Dalı, Ankara, Türkiye ORCID: 0000-0002-3661-3488

3 Cemile Merve Seymen, Gazi Üniversitesi Tıp Fakültesi Histoloji ve Embriyoloji Anabilim Dall, Ankara, Türkiye ORCID: 0000-0002-8945-3801

Geliş: 25.04.2017, Revizyon: 25.05.2017, Kabul Tarihi: 05.10.2017

\section{Özet}

Başarılı bir üreme döngüsü sağlıklı aydınlık/karanlık döngüye sahip fizyolojik koşullarla doğrudan ilişkilidir. Sirkadyan ritim olarak da ifade edilen, bu aydınlık karanlık döngü memeli üreme sistemleri için önemlidir. Özellikle dişi üreme döngüsü ovulasyon ve sirkadyan ritmi içeren kompleks bir süreçtir. Bu kompleks süreçte antioksidan aktivitesiyle melatonin çok önemli bir yere sahip olmakla birlikte, melatonin sentezleyen organ listesi yapılan çalışmalar ışığında gün geçtikçe artmakta ve bu organların arasında ovaryum da yer almaktadır Dolayısı ile pineal bezin yanısıraovaryumda da melatonin sentezlendiği ve sentezlenen melatoninin foliküler sıvıya salındığı ileri sürülmektedir. Benzer şekilde in vitrofertilizasyon (IVF) çalışmalarında medyuma melatoninin eklenmesi ile tedavide pozitif sonuçlar elde edilmiştir. Bu derlemede, karanlığın mucizesi olan melatoninin genel özelliklerini ve özellikle son yıllarda yapılan çalışmalar ile ortaya konulan ovulasyon-melatonin ilişkisini farklı yönleri ile ele almayı amaçladık.

Anahtar kelimeler: Melatonin, Ovaryum, Folikülogenezis

DOI: $10.5798 /$ dicletip.407249

Yazışma Adresi / Correspondence: Gökçe Nur Yücel, Gazi Üniversitesi Tıp Fakültesi Histoloji ve Embriyoloji Anabilim Dalı 06500 Beșevler, Ankara, Türkiye e-mail: gnuryucel@gmail.com 


\title{
The Miracle of Darkness: Melatonin and Interaction in Ovary
}

\begin{abstract}
Successfully reproductive cycle is directly associated with physiological conditions which have healthy light/dark cycle. This light/dark cycle, also called as circadian rhythm, is important for mammalian reproductive systems.

Particularly, female reproductive cycle is a complex process involving ovulation and circadian rhythm. Melatonin is very important in this complex process with its anti-oxidant activity. The list of organs that synthesizing melatonin is increasing day by day and the ovary is also present between these organs. Therefore, it is suggested that melatonin is synthesized in the ovary as well as the pineal gland and synthesized melatonin is released into the follicular fluid. Similarly, positive results have obtained in in vitro fertilization (IVF) studies with the addition of melatonin in the IVF medium. In this review, we aimed to explain the general properties of the miracle of darkness, melatonin and relationship between ovulation and melatonin with different aspects, which has been revealed in recent years.
\end{abstract}

Keywords: Melatonin, Ovarium, Folliculo genesis

\section{GİRIS}

Tüm canlılar için en önemli süreçlerden biri, üremedir ${ }^{1}$. Bașarılı bir üreme döngüsü ise, normal aydınlık / karanlık döngü ve bununla ilişkili fizyolojik koşullara bağlıdır. Bu fizyolojik koşullarda en önemli etkilerden birini, üretimi aydınlık ve karanlık ritimle düzenlenen melatonin hormonu sağlamaktadır ${ }^{1}$.Dişi üremesi açısından bakıldığında ise ovulasyon, hormonal ve sirkadiyen ritmi de içeren kompleks bir süreç olarak karşımıza çıkmaktadır. Bu kompleks sürecin kalitesini arttıran önemli biyolojik moleküllerden birisinin de yine melatonin olduğu yapılan çalışmalarla ortaya konulmuştur ${ }^{2}$.

$\mathrm{Bu}$ derlemede, karanlığın mucizesi olan melatoninin genel özelliklerini ve özellikle son yıllarda yapılan çalışmalar ile ortaya konulan ovulasyon-melatonin ilişkisini farklı yönleri ile ele almayı amaçladık.

\section{Melatonin (N-acetyl-5-methoxytryptamine)}

Geceleri pineal bezden salınan, metabolitleriyle birlikte lipofilik yapıda hormon olan ve fertilitenin düzenlenmesinde kompleks etkiye sahip olan melatonin ${ }^{3}$ ilk olarak sığır epifiz bezinden izole edilmiş ${ }^{4}$ ve melatoninin kurbağa melanositlerinin rengini açan bir ajan olduğu ifade edilmiștir ${ }^{5}$. Melatonin, sirkadiyen ritimde önemli bir fonksiyona sahiptir ${ }^{6}$ veamfipilik bir molekül olması dolayısıyla morfolojik bariyerleri kolaylıkla geçebilmenin yanısıra reaktif oksijen türleri (ROS)'nin neden olduğu oksidatif strese karşı dahücrelerin koruyucusu olarak işlev görmektedir6. Melatonin ve metabolitlerinin hücreleri koruyucu etkisi, melatoninindirekt ve indirekt antioksidan özellikleriyle ilişkilidir ${ }^{7}$. Bu bağlamda ROS ve reaktif nitrojen türlerinin (RNS) uzaklaştırılması direkt antioksidan özellik olarak ifade edilebilirken, indirekt aktivitesi isemelatonin metabolitlerinin antioksidan aktivitesiyle ilişkilendirilmiştir ${ }^{8}$.

\section{Melatonin Sentezi}

Melatonin sentezi postnatal dönemde 3. aydan itibaren artmakta veerişkinlerde, aydınlığa nazaran karanlıkta 3-10 kat arasında daha fazla sentezlenmektedir ${ }^{9}$. Bunun nedeni, ışığın retina ve suprakiazmatik çekirdek (SCN) üzerinden süperiorservikalganglionu (SCG) inhibe etmesi ve böylelikle SCG'nin aydınlık periyod süresince epifiz bezini uyaramamasıdır. Karanlıkta retinal inhibisyonun kalkmasıyla, SCG adrenerjik yolak tarafından epifiz bezini uyarmakta ve siklikadenozinmonofosfat (cAMP) yolağ 1 üzerinden $\mathrm{N}$-asetiltransferaz aktivasyonu ilemelatonin üretimini uyarmaktadır ${ }^{10}$. Melatonin epifiz bezi bașta olmak üzere; karaciğer, retina, ovaryum, kan 
damarlari ${ }^{10}$ tarafindan sentezlenmektedir. Melatonin sentezinde temel biyomolekül, triptofan amino asitidir. Triptofan, triptofan hidroksilaz enzimi tarafindan 5hidroksitriptofona çevrilir. 5-hidroksitriptofan, aminoasit dekorbaksilazla serotonine; serotonin, $\mathrm{N}$-asetil transferazla $\mathrm{N}$-asetil serotonine; $\mathrm{N}$-asetil serotonin de metiltransferaz enzimi aracılı̆ dönüștürülmektedir ${ }^{10}$. Üretilen lipofilik yapıdaki melatonin kapillerlere ve oradan da hücrelere geçmektedir9. Melatoninin inhibisyonu ise karaciğerde gerçekleşmektedir ${ }^{11}$.

\section{Antioksidan Olarak Melatonin}

Hücreler için zararlı olan ROS ve RNS (reaktif nitrojen türleri) metabolitlerine karşı hücresel koruma mekanizmaları bulunmaktadır. Melatonin bu süreçte özellikle ROS ve RNS'ye karşı koruyucu antioksidan olarak görev yaparken, aynı zamanda serbest radikal süpürücü olarak da çok sayıda antioksidan enzimi aktive etmektedir ${ }^{12}$.

\section{Melatonin ve Sirkadiyen Ritim}

İnsanlarda melatoninin sirkadiyen ritimde ilk aktivitesi postnatal dönemin 9. haftasında görülürken, melatonin salınımının maksimum düzeylere ulaştığı dönem 3.-5. yıllar olarak tanımlanmaktadır ${ }^{1}$. Sirkadiyen döngü olarak da ifade edilen bu değişimler, anterobazal hipotalamusta bulunan küçük bilateral nöron grubu olarak ifade edilen SCN kökenlidir ${ }^{1}$. Çok sayıda periferik doku hem sempatik hem de parasempatik otonom sinir sistemi tarafindan innerve edilmediğinden bu dokulara sinyaller, ikinci bir sinyal ileti sistemi olan melatoninin sirkadiyen döngüsünde, kan doku aracılığıyla iletilmektedir ${ }^{1}$. Bu sistemde gelen sinyali okuyacak ve cevap oluşturacak membran bağımlı reseptör sistemi ise 7-transmebran G protein eşlikli reseptör aile üyesiolan melatonin reseptör-1 (MT1) melatonin reseptör-2 (MT2) ve quinone reductase 2A enzimi olan melatonin reseptör 3 (MT3) olarak tanımlanmıştır ${ }^{14}$. Bu reseptörler melatoninin sirkadiyen sisteminden etkilenen bütün hücrelerde bulunurken, melatonin aynı zamanda bu reseptör sisteminden bağımsız olarak serbest oksijen radikalleri üzerinden de hücrelere etki etmektedir ${ }^{1}$.

\section{Melatonin ve Dişi Üreme Sistemi}

Epifiz bezinin melatonin sentezinde temel organ olduğu bilinmekle birlikte ${ }^{4}$, melatonin sentezleyen organ listesi yapılan çalışmalar ışığında gün geçtikçe artmakta ve bu organların arasında ovaryum da yer almaktadır ${ }^{1}$. Eş zamanlı olarak yapılan ölçümlerde ovaryumdaki melatonin seviyesinin dolaşımdaki melatonin seviyesinden fazla olduğu ve folikül büyüdükçe ovaryan melatonin miktarının arttığı tespit edilmiştir ${ }^{1}$. Yapılan çalışmalarda bütün olarak ovaryumun, kumulus ooforusu oluşturan granüloza hücrelerinin ve oositin de melatonin sentezlediği rapor edilmiştir 1 . Ovaryumdaki melatonin, progesteron üretimiyle ilişkilidirve diğer ekstrapineal organlarda üretilen melatoninde olduğu gibi, ovaryumda üretilen melatonin de dolaşıma verilmemektedir ${ }^{15}$.

Melatonin, dişi üreme sistemi üzerindeki aktivitesini özellikle ovulasyon süresince üretilen serbest oksijen radikallerinin neden olduğu hasar üzerinde göstermektedir6́. Ovulasyon sürecinde makrofajlar, nötrofiller, parankimal steroidogenik hücreler veendotelyal hücreler tarafından ROS üretilmektedir ${ }^{16}$. Maruz kaldığı ROS'a rağmen sağlıklı embriyoların olması, folikülün oksidatif stresten korunduğunu gösteren en önemli bulgu olarak karşımıza çıkmaktadır. Söz konusu bu durumun ise oositte kumulus ooforus ve oosit tarafından üretilen ve antioksidan olarak işlev gören endojen melatonin tarafından sağlandığ belirtilmektedir ${ }^{15}$. Melatoninin oksidatif hasara maruz kalmış embriyolarda in vitro fertilizasyon (IVF) ve embriyo transferi (ET) sonuçlarını arttırdığı yapılan çalışmalarda 
gösterilmiștir ${ }^{17}$. ROS oositin olgunlaşmasına ve foliküler yırtılmaya yardımcı olmasına rağmen, aşırı sentezlendiğinde sub-fertiliteyle sonuçlanacak şekilde oosit sayısında azalmaya neden olmaktadır ${ }^{18}$. Buradan yola çıkılarak oositteki ROS üretimi ve yıkımının oositte denge içinde gerçekleştiği söylenebilmekte ve oositte endojen melatonin sentezinin bu dengede anahtar bir role sahip olduğu ifade edilmektedir ${ }^{1}$. Melatoninin aynı zamanda granüloza hücrelerinin luteinizasyonu esnasında gerçekleşen progesteron üretiminde infertiliteye neden olabilecek oksidatif hasardan oositi koruduğu da ifade edilmektedir ${ }^{15}$.

\section{Ovaryum ve Melatonin Reseptörleri}

Melatoninin bazı aktiviteleri membran reseptörleri aracılığıyla gerçekleşmektedir. Membran melatonin reseptörlerinin 3 alt türübelirlenmiştir. BunlardanMT1 ve MT2 G protein-eşlikli, 7-transmembran domain, reseptör ailesine aittir ${ }^{19}$. Bu reseptörlerin aracı olduğu sinyal yolağında hedef hücrede adenilat siklaz inhibe edilmektedir 3. reseptör olan MT3 ise bazı hayvanlarda bulunan ve G-protein eşlikli reseptör olmayan ve insanlarda quinone redüktaz (QR2) olarak tanımlanan bir enzim homoloğudur ${ }^{19}$. Tüm melatonin reseptörlerinin aktivasyonu, cyclic adenosine 3'5' monophosphate (cAMP) ile indüklenen Protein kinaz A'nın üretimini azaltır. İnsanlarda MT1 ve MT2 reseptörleri birçok organda tanımlanmıştır; bu organlar arasında beyin, retina, kardiyovasküler sistem, karaciğer, safra kesesi, bağırsak, böbrek, immün sistem hücreleri, adipositler, prostat, meme epitel hücreleri, myometriyum ve deri bulunmaktadır ${ }^{17}$. Yapılan çalışmalarda rat ovaryum dokusundaki melatonin reseptörlerinin proöstros döngüde, metöstrus döngüden daha fazla olduğu ve granüloza hücrelerininMT1 reseptörü için temel bölge olduğu belirlenmiştir ${ }^{13}$.

\section{Ovaryumda Melatonin ve Foliküler Büyüme}

İnsan foliküler sıvısında plazma ile bağlantılı olarak bulunmakta olan ve granüloza hücre steroidogenezisi ile foliküler fonksiyonu etkilemeyen melatonin, ovaryum fonksiyonunu direkt olarak etkilemektedir ${ }^{20}$.

Ovaryan folikülerin büyümesi endokrin, parakrin ve otokrin mekanizmaları içeren kompleks bir süreç olarak karşımıza çlkmaktadır ${ }^{17}$. Folikülogenezis ovaryan foliküler havuzda başlayan ve primordiyal folikülün primer, preantral ve antralfoliküle gelişmesi ve ovulasyon ile sonuçlanan bir süreçtir ${ }^{17}$. Folikülogenezisde çok sayıda folikül ovulasyon için birlikte gelişmeye başlarken, gelişen foliküllerden yalnızca biri olgunlaşır, diğerleri ise atretik hale gelir ${ }^{17}$.

Antral kaviteyi dolduran foliküler sıvıda dönemsel dalgalanmalar görülmekte ve preovulatuar folikülde serum seviyesinden fazla oranda melatonin bulunmaktadır ${ }^{21}$. Tüm bu verilerden yola çıkılarak ovaryumda melatonin sentezlendiği ve sentezlenen melatoninin foliküler sıvıya salındığ ileri sürülmektedir ${ }^{22}$. Bunun yanı sıra IVF'te de oral yolla melatonin takviyesi alan infertil kadınlarda foliküler sıvıda melatonin miktarında artış gözlenmiştir ${ }^{17}$.

Ovulasyona girecek folikülü seçmedeki temel mekanizmanın granüloza hücrelerindeki luteinleştirici hormon (LH) reseptörlerini kodlayan mesajcl RNA (mRNA) ekspresyon seviyesiyle ilişkili olduğu öne sürülmüş ${ }^{23}$ ve insanlarda melatonin uygulaması sonucunda granüloza hücrelerinde $\mathrm{LH}$ reseptörlerinin arttığl görülmüştür ${ }^{20}$. Benzer şekilde melatoninin ovulasyon süresince foliküler olgunlaşmada seks steroid hormon üretimini de etkilediği bildirilmiştir ${ }^{20,23}$. Foliküler büyüme süresince gonadotropinler ile birlikte lokal olarak üretilen insülin benzeri büyüme faktörleri (IGFs) ve dönüştürücü büyüme faktörü- $\beta$ (TGF- $\beta$ ) süper ailesi de hareket etmektedir ${ }^{26}$. 
Mitojenik ve anti-apoptotikpeptid özelliğinde, farklılaşmayı teşvik ederek aynı zamanda yüksek afiniteye sahip reseptörler aracılı̆̆ıla insülin benzeri metabolik etkiye sahip olan IGF, granüloza hücrelerinden foliküler büyüme süresince üretilmektedir ${ }^{26}$. IGF-I ve IGF-II DNA sentezini stimüle etmekle birlikte ${ }^{24}$, IGFI'inovaryan foliküllerde anti-apoptotik aktiviteye sahip olduğu bildirilmiştir. Aynı zamanda ovaryan apoptozis IGF-bağlayan protein (IGFBP) tarafindan da arttırılmaktadır ${ }^{25}$. Melatoninin ise insan granüloza hücrelerinde IGF-I üretimini stimüle ettiği bildirilmiştir ${ }^{26}$. Melatoninin ayrıca IGFIreseptörünü indüklediği ve hücre metabolizması ile ilişkili olan P13K/AKT sinyal yolağı ile hücre proliferasyonu, büyümesi ve farklılaşmasında rol alan MEK/ERK sintraselüler yolağını aktive ettiği de bilinmektedir ${ }^{27}$. TGF- $\beta$ süper ailesi ise, ovaryan hücreler ve oosit tarafindan eksprese edilmekte ve folikül gelişiminde intra-ovaryan regülatör olarak görev yapmaktadır ${ }^{24,32}$. İnsanlarda, TGF$\beta$ teka ve granüloza hücrelerinin her ikisi tarafından da üretilmekte ${ }^{29}$ ve folikül uyarıcı hormon (FSH) reseptör ekspresyonunu stimüle etmektedir ${ }^{30}$. Farelerde melatonin tedavisinin TGF- $\beta$ gen ekspresyonunu artırdığı yapilan çalışmalarla belirlenmiştir ${ }^{31}$. TGF- $\beta$ aile üyesi olan kemik morfogenik protein-15 (BMP-15) ve büyüme farklılaşma faktörü-9 (GDF-9)'un büyümekte olan antral folikülde önemli bir role sahip olduğu gösterilmiştir ${ }^{29}$.

\section{Melatonin ve Foliküler Atrezi}

Atrezi; proapoptotik ve antiapoptotik faktörler tarafından düzenlenen bir süreç olmakla birlikte foliküler atrezi, apoptozis ve nitrik oksit (NO) üretimi arasında bir bağlantı söz konusudur ${ }^{24,31}$. Foliküler büyüme süresince üretimi artan fagositik makrofaj ve endotelyal hücreler, ovaryumda ROS üretimine neden olmaktadırlar ${ }^{16}$.Antioksidan enzimlerin azalmış seviyeleri ile süperoksit dismutaz (SOD), glutatyon peroksidaz (GPx) vekatalaz mRNA ekspresyonunun artmış oranları atretik foliküller deoksidatif stres aracılı apoptozise yardım etmektedir ${ }^{30}$. $\mathrm{Bu}$ enzimler normal koşullarda granüloza hücrelerini serbest oksijen hasarından ve atrezi baskısından korumaktadırlar ${ }^{30}$. Yapılan çalışmalarda melatonin uygulamasinın diabetus mellitus ratlarda apoptozisi azalttığ ve bu ratlarda NF$\mathrm{Kb}$ ve caspase-3 inovaryum patofizyolojisinde önemli bir role sahip olduğu belirlenmiștir ${ }^{40}$.

Antral folikül deatretik degradasyonun düzenlenmesi için $\mathrm{Bcl} 2$ aile üyeleri oldukça büyük öneme sahiptir, granüloza hücrelerinde Bcl2'nin aşırı ekspresyonu bu hücrelerde apoptozisi azaltmaktadır ${ }^{32}$. Kaspazlar da foliküler atreziyi etkilemektedirler ${ }^{31}$. Son zamanlarda yapılan çalışmalarda melatoninin Bcl2 ekspresyon indüksiyonuna ve Kaspaz-3 aktivitesinde azalmaya neden olduğu ve dolayısı ile apoptozisin mitokondriyal yolağının indüksiyonundan dokuyu koruduğu gösterilmiştir ${ }^{17}$.

Foliküler melatoninin artması büyüyen folikül deatreziden kaçmak için önemli bir faktördür ve intrafoliküler melatonin miktarı atreziyle doğrudan ilişkilidir ${ }^{17}$.

\section{Melatonin ve Ovulasyon}

Ovulasyon denilen karmaşık süreç LH ve steroid, NO, prostaglandinler ve peptidleri içeren lokal faktörlerin etkisi altındadır. LH salınımı, biyokimyasal ve yapısal değișiklikleri tetiklemektedir ${ }^{17}$. $\mathrm{Bu}$ değişiklikler Graaf folikülün ruptüre olmasına neden olmaktadır. Progesteron üretimi luteinizasyon ve ovulasyon için temeldir. Progesteron ve östradiol konsantrasyonuna benzer şekilde melatonin konsantrasyonu da insanlarda küçük foliküllere nazaran büyük foliküllerde daha fazladır ${ }^{17}$. İlginç şekilde foliküler progesteron ve melatonin konsantarsyonu arasında doğru orantı söz konusudur ${ }^{15}$. Foliküldeki yükselmiş melatonin miktarının, luteinizasyon ve ovulasyon sonrasında yükselmiş progesteron üretimiyle ilişkili olabileceği belirtilmektedir. Ovulasyonla birlikte ovaryan progesteronun, 
anjiyotensin-II'nin ve nitrik oksit sentetazın (NOS) lokal üretimleri de artmaktadır ${ }^{33}$. Bu vazoaktif moleküller foliküler kan akışının kontrolünde temel role sahiptirler ${ }^{17}$.

Başarılı bir ovulasyonun yükselmiş progesteron ve östrodiol seviyelerine ihtiyaç duyduğu bilinmektedir ${ }^{10,34}$. Melatonin, prostaglandin ve östrasdiol unovulasyondaki ilişkisi arasında net bir bilgi bulunmamakla birlikte, ratlar üzerinde yapılan bir çalışmada gastrik mukozada melatonin tedavisinin önemli ölçüde prostaglandin ve östradiol konsantrasyonunu arttırdığı gösterilmiştir ${ }^{34}$.

\section{Melatonin ve Luteinizasyon}

Foliküler hücrelerde LH reseptör aktivasyonu ovulasyonun temel mekanizmasinı ve ovule folikülde korpus luteumda terminal farklılaşmamın temelini oluşturmaktadır ${ }^{35}$. Preovulatuvar foliküllerde LH reseptör aktivasyonu ovulasyonun yanı sıra korpusluteumda, luteinizasyon denilen süreci de programlamaktadır. Folikülogenezisde ortaya çıkan ROS, melatoninin granüloza hücrelerinden sentezlenmesini stimüle ettiği prostaglandinin üretimini baskllamakta ve korpus luteum dönüşümünü indüklemektedir 35 . Melatonin, bahsedilen bu özelliklerinin yanısıra, aynı zamanda, korpus luteumuinsan luteal hücrelerinde progesteron üretimini inhibe eden reaktif oksijen türlerinin hasarlarından da korumaktadır ancak lüteinizasyondaki melatonin aktivesi tam olarak anlaşılmış değildirr ${ }^{13}$.

\section{Melatonin, Oosit Kalitesi ve Embriyo Gelişimi}

Oositin mayotik olgunlaşması süresince, oositte oksidatif stresin yanısıra mRNA, protein, lipid ve şeker birikimi olaylanmaktadır. Fertilizasyondan sonra ooplazma, embriyo stoplazması haline gelmekte ancak spermatozoonun bu sürece katkısı minimal seviyede olmaktadır. Bu nedenle oositte ROS'un neden olduğu oksidatif stres, yüksek kalitedeki embriyo olarak da tanımlanabilecek olan iyi gelişmiş embriyo için sınırlanmalıdır. Çünkü ROS membran lipid peroksidasyonunu indüklemekte ve oositte DNA hasarına neden olmaktadir ${ }^{1,17}$.

Yapılan bir çalışmada araştırmacılar, melatoninin domuz oositine etkisini incelemişler ve IVF süresince $10 \mathrm{ng} / \mathrm{ml}$ melatoninin olgunlaşma medyumuna eklendiği uygulamanın ROS'da azalmaya neden olduğunu saptamışlardır ${ }^{36}$. Araştırmacılar yaptıkları bir başka çalışmada ise melatoninin domuz embriyo gelişimi üzerine etkilerini incelenmişler ve 10-9 M melatoninle desteklenen deney grubunda fertilizasyon oranlarında artış gözlemlemişlerdir ${ }^{37}$.

\section{Melatonin ve Polikistik Over Sendromu}

Polikistik over sendromu (PKOS), doğurganlık çağındaki kadınlarda en sık görülen endokrin bozukluk olarak karşımıza çlkmaktadır ${ }^{39}$. Günümüzde PKOS hakkında önemli gelişmeler kaydedilmiş olunmasına rağmen, sendromun etyopatogenezi ve tanı kriterleri hakkında çalışmalar halen devam etmektedir. PKOS'aklinikte oligo-amenore, disfonksiyonel uterus kanaması gibi menstrual düzensizlikler, hirşutizm, akne, ciltte yağlanma, androjenik alopesi gibi hiperandrojenizm bulgular, infertilite, obezite, fizik incelemede nadiren virilizasyon ve akantosisnigrikans, insulin direnci ve beraberinde kompensatuar hiperinsulinemi gibi bulgular eşlik etmektedir ${ }^{39}$. PKOS'da ovaryan hiperandrojenizm ve değişmiş intraovaryan parakrin sinyalizasyon folikül büyümesini bozabilmekte ve foliküler gelişimin duraksamasına bağlı olarak, overin periferinde küçük antral foliküllerin birikiminin eşlik ettiği polikistik morfoloji gözlenmektedir. Bu nedenle polikistik over sendromunda, over dokusu makroskopik olarak normal over büyüklüğünün 2-5 katı kadardır ${ }^{39}$. Ayrıca PKOS'lu kadınlarda folikülogenez süresince intra foliküler mikroçevrede oluşan değişiklikler, endokrin-parakrin faktör 
değişikliği, metabolik disfonksiyon ile ilişkili olarak bozulmuş oosit maturasyonu, düşük fertilizasyon oranları ve embriyonik gelişim yetersizliği gözlenmektedir ${ }^{39}$ ve PKOS'lu kadınlarda, melatonin döngüsünde de bozulmaların saptandığı, karanlık döngülerinin PKOS'lu olmayan kadınlara kıyasla daha kısa olduğuda belirlenmiştir ${ }^{39}$. Melatonin ise antioksidan superoksit dismutaz, glutatyon peroksidaz ile katalaz gibi antioksidan enzimlerin sentezlerini düzenlemektedir ${ }^{30}$. Melatonin ayrıca IGF ve TGB- $\beta$ gibi faktörlerin sentezleri arttırmak yoluyla da antioksidan gibi davranmaktadır. Buradan yola çıkarak, artan foliküler melatonin konsantrasyonunun büyüyen foliküller deatreziden kaçmak için önemli bir faktör olduğu söylenebilir.

\section{SONUÇ}

$\mathrm{Bu}$ kısa derlemede, karanlığın mucizesi olarak da nitelendirilebilecek olan melatoninin dişi üreme sistemi üzerindeki temel rollerini, antioksidan aktivitesi üzerinden özetlemeyi amaçladık.

Özellikle son yıllarda yapılan çalışmalarla melatoninin gerek folikül ogenezis üzerindeki, gerek IVF mediumlarında oosit maturasyonu ve embriyo gelişimi üzerindeki olumlu etkileri ve gerekse poliksitik over sendromlu bireyler üzerindeki oosit koruyucu etkileri ortaya konulmaktadır. Her konuda olduğu gibi, bu denli önemli görevler üstlenen endojen antioksidan olan melatonin ile ilgili de, özellikle ajanın terapötik aktivitesi ve tam etki mekanizmasını aydınlatabilecek ilave çalıșmalara ihtiyaç duyulduğu görüşündeyiz.

Çıkar Çatışması Beyanı: Yazarlar çıkar çatışması olmadığını bildirmişlerdir.

Finansal Destek: Bu çalışma her hangi bir fon tarafından desteklenmemiştir.

Declaration of Conflicting Interests: The authors declare that they have no conflict of interest.
Financial Disclosure: No financial support was received.

\section{KAYNAKLAR}

1. Reiter RJ, Tamura H, Tan DX, et al. Melatonin and the circadian system: Contributions to successful femalere production. Fertility and Sterility. 2014;102:321-8

2. Coelho LA, Peres R, Amara FG, et al. Daily differential expression of melatonin-related genes and clock genes in rat cumulus-oocyte complex: changes after pinealectomy. J. Pineal Res. 2015;58:490-9.

3. Kandemir YB, Aydin C, Gorgisen G. The effects of melatonin on oxidative stress and prevention of primordial follicle loss via activation of mTOR pathway in the rat ovary. Cellular and Molecular Biology. 2017; 63: $100-6$

4. Lerner $A B$, Case JD, Takahashi Y,et al. Isolation of melatonin, the pineal gland factor that lightens melanocytes. J. Am. Chem Soc. 1958;80:2587.

5. Lerner AB, Case JD, Takahashi Y. Isolation of Melatonin and 5-Methoxyindole-3-acetic acid from bovine pineal glands. The Journal Of Biological Chemistry. 1960; 235.

6. Tamura H, Takasaki A, Taketani T, et al. Melatonin and female reproduction. J Obst Gynec Res. 2014; 40:1-11.

7. Cruz MH, Leal CLV, Cruz JF,et al. Essential actions of melatonin in protecting ovary from oxidative damage. Theriogenology. 2014;82:925-32.

8. Reiter RJ, Manchester LC, Tan DX Neurotoxins: Free Radical Mechanisms and Melatonin Protection Curr Neuropharmacol. 2010 Sep;8:194-210.

9. Reiter RJ. The melatonin rhythm: Both a clockand a calendar. Experientia. 1993;49:654-64.

10. Kierszenbaum AL. Histoloji ve Hücre Biyolojisi (Türkçe çeviri). Ankara: Palme Yayıncılık; 2006:565-85.

11. Semak I, Korik E, Antonova M, et al. Metabolism of melatonin bycytochrome P-450s in rat liver mitochondria and microsomes. J PinealRes. 2008;45:515-23.

12. Nikmard F, Hosseini E, Bakhtıyarı M et al. Effects of melatonin on oocyte maturation in PCOS mouse model. Animal Science Journal (2017) 88,586-92.

13. He C, Ma T, Shi J et al. Melatonin and its receptor MT1 are involved in the down stream reaction to luteinizing hormone and participate in the regulation of luteinization in different species. Journal of Pineal Research. 2016 Oct; 61:279-90. 
14. Tao J, Lv J, Li W et al. Exogenous melatonin reduced blood pressure in late-term ovine fetus via MT1/MT2 receptor pathways. Reproductive Biology 16 (2016) 212-7.

15. Tamura H,Nakamura Y, Takiguchi S, et al. Melatonin directly suppresses steroid production by preovulatory follicles in the cyclic hamster, J PinealRes, 25 (1998), pp. 135-41.

16. Agarwal A Oxidative stress and its implications in female infertility - a clinician's perspective. Reproductive Bio Medicine;2005;11:641-50.

17. Tamura $H$, Takasaki $A$, Ichiro $M$, et al. Oxidative stress impairs oocyte quality and melatonin protects oocytes from free radical damage and improves fertilization rate. J Pineal Res. 2008;44:280-7.

18. Roychoudhury S, Agarwal A, Virk G, et al. Potential role of green tea catechins in the management of oxidative stress-associated in fertility. Reproductıve Biomedicıne Onlıne 34 (2017)487-8.

19. Von GC, Stehle JH, Weaver DR Mammalian melatonin receptors: Molecular biology and signal transduction. Cell Tissue Res. 2002;309:151-62.

20. Woo MMM, Tai CJ, Kang SK, et al. Direct action of melatonin in human granulosa-luteal cells. J Clin Endocrinol Metab. 2001;86:4789-97.

21. Maitra SK, Chattoraj A, Mukherjee S et al. Melatonin: A potent candidate in the regulation of fish oocyte growth and maturation. General and Comparative Endocrinology 181 (2013)215-22.

22. Sakaguchi K, Itoh MT, Takahashi $\mathrm{N}$, et al. The rat oocyte synthesises melatonin. Reprod Fertil Dev. 2013;25:674-82.

23. Danforth DR. Endocrine and paracrine control of oocyte development. American Journal of Obstetrics \& Gynecology 1995;172:747-52.

24. Drummond AE. The role of steroids in follicular growth. Reprod Biol Endocrinol. 2006;10:4-16.

25. Adriaens I, Jacquet $P$, Cortvrindt R, et al. Melatonin has dose-dependent effects on folliculogenesis, oocyte maturation capacity and steroidogenesis. Toxicology. 2006; 228:333-43.

26. Poretsky L, Cataldo NA, Rosenwaks Z, et al. The insulin-related ovarian regülatöry system in health and disease. Endocrinol Rev. 1999;20:535-82.

27. Chun SY, Billig H, Tilly JL, et al. Gonadotropin suppression of apoptosis in cultured preovulatory follicles: mediatory role of endogenous insulin-like growth factor I. Endocrinology. 1994;135:1845-53.
28. Picinato MC, Hirata AE, Cipolla-Neto J, et al. Activation of insulinand IGF-1 signaling pathways by melatonin through MT1 receptor in isolated rat pancreatic islets. J PinealRes. 2008; 44:88-94.

29. Knight PG, Glister C. TGF-beta süper family members and ovarian follicle development. Reproduction. 2006;132:191-206.

30. Tatemoto H, Muto N,Sunagawa I, et al. Protection of Porcine Oocytes Against Cell Damage Caused by Oxidative Stress During In Vitro Maturation: Role of Superoxide Dismutase Activity in Porcine Follicular Fluid. BiolReprod (2004)71:1150-7.

31. Ratts VS, Flaws JA, Kolp R, et al. Ablation of bcl-2 gene expression decreases the numbers of oocyte sand primordial follicles established in the post-natal female Mouse gonad. Endocrinology. 1995;136:3665-8.

32. Tilly JL, Tilly KI Inhibitors of oxidative stress mimic the ability of follicle- stimulating hormone to suppress apoptosis in cultured rat ovarian follicles. Endocrinology. 1995; 136:242-52.

33. Matikainen T, Perez GI, Zheng TS, et al. Caspase-3 gene knockout defines cell lineage specificity for programmed cell death signaling in the ovary. Endocrinology. 2001;142:2468-80.

34. Nakamura $Y$, Tamura $\mathrm{H}$, Takayama $\mathrm{H}$, et al. Increased endogenous level of melatonin in preovulatory human follicles does not directly influence progesterone production. Fertil Steril. 2003; 80:1012-6.

35. Wetterberg L, Arendt J, Paunier L, et al. Human serum melatonin changes during the menstrual cycle. J Clin Endocrinol Metab. 1976;42:185-8.

36. Manca ME, Manunta LM, Spezzigu A, et al. Melatonin deprival modifies follicular and corpus luteal growth dynamics in a sheep model. Reproduction. 2014; 147:885-95.

37. Tamura $H$, Takasaki $A$, Taketani $T$, et al. The role of melatonin as an antioxidant in the follicle. Journal of Ovarian Research. 2012;5:5.

38. Rodriguez-Osorio N, Kim IJ, Wang H, et al. Melatonin increases cleavage rate of porcine preimplantation embryos in vitro. J Pineal Res. 2007; 43:283-8.

39. Piskinpasa S, Yıldız BO. Polikistik over sendromu. Hacettepe Tip Dergisi. 2005;36:168-74.

40. Nayki U, Onk D, Balci G et al. The effect of melatonin on oxidative stress and apoptosis in experimental diabetes mellitus-related ovarian injury. Gynecol Endocrinol, 2016; 32:421-6. 